\title{
Assessment of Extended Aeration Sludge Process in Jahra Wastewater Treatment Plant-Kuwait
}

\author{
Saud B. Al-Shammari and A. Shahalam
}

\begin{abstract}
This study evaluates and analyzes the performance and the efficiency of extended aeration sludge process (EASP) utilized in Jahra conventional wastewater treatment plant in Kuwait. The performance evaluation will help for the better understanding of design and operating difficulties of Jahra wastewater treatment plant. For this purpose, weekly samples from Jahra raw wastewater line, aerator effluent stream and clarifier effluent line were collected and analyzed for important wastewater quality parameters. The performance evaluation was done based on removal efficiency of Biochemical Oxygen Demand (BOD), Chemical Oxygen Demand (COD), Total Suspended Solids (TSS), Total Nitrogen (TN) and Total Phosphorus (TP). The results indicated that a significant reduction in TSS, BOD, COD was observed in EASP effluent. The results show that the average removal efficiencies of the system for TSS, BOD, COD were $86 \%, 85 \%$ and $81 \%$, respectively. However, poor reduction in phosphate and nitrogen contents was noticed with average removal of $57 \%$ and $42 \%$ respectively.
\end{abstract}

Index Terms-Activated sludge process, wastewater, treatment.

\section{INTRODUCTION}

Because of severe environmental impact of dumping wastewater into sea, Kuwait established wastewater treatment plants around the country in late 1950's [1]. In recent years, treatment of wastewater in Kuwait has become essential not only for environmental protection of aquatic ecosystem but also for augmenting limited water resources by reusing of treated wastewater [2]. The collected sewage in Kuwait is treated in four main wastewater treatment systems located at Um-Alhaiman, Sulaibiya, Riqqa and Jahra. The sewage treatment plants in Kuwait generally employ the activated sludge treatment process. The basic principal behind all activated sludge processes is that as microorganisms grow, they form particles that clump together. These particles (floc) are allowed to settle to the bottom of the tank, leaving a relatively clear water free of organic material and suspended solids [3]. The effluent from secondary treatment plants at Riqqa and Jahra receives tertiary level treatment of sand filtration. The Sulaibiya plant started operation in August 2004. The plant provides advanced treatment through Ultrafiltration, Reverse Osmosis and Ultra-violet ray processes to refine secondary effluent

Manuscript received October 12, 2018; revised December 5, 2018.

Saud Al-Shammari is with Environmental Health Departments, College of Health Science, The Public Authority for Applied Education and Training, P. O. Box 14281, Faiha 72853 Kuwait (e-mail: sb.alshemmari@paaet.edu.kw s.b.alwan@gmail.com, salalwan@gmail.com,

Abu-Albasher Shahalam is with a Private Company, Kuwait (e-mail: shaalam@gmail.com). from the biological process. The treated effluents of all three plants are used for irrigation purposes. The aim of this study is to evaluate the treatment efficiency and the effluent quality of the extended aeration sludge system in Jahra wastewater treatment plant.

\section{BACKGROUND}

\section{A. Extended Aeration Sludge Process}

The extended aeration sludge process (EASP), which is a modification of the conventional activated sludge process is widely used to treat domestic wastewater. EASP is designed to provide an aeration period much longer than the conventional activated sludge process (generally 18-24 hours) followed by a 3-6 hour period in a final settling tank for separation of the liquid and the sludge [4]. Fig. 1 illustrate the process flow diagram of EASP. The flow scheme of EASP is similar to that of the completely mixed process except that primary settling is omitted. The process employs long aeration time, high MLSS (Mixed Liquor Suspended Solids) concentration and therefore low F/M (Food Micro Organisms ratio) [5].

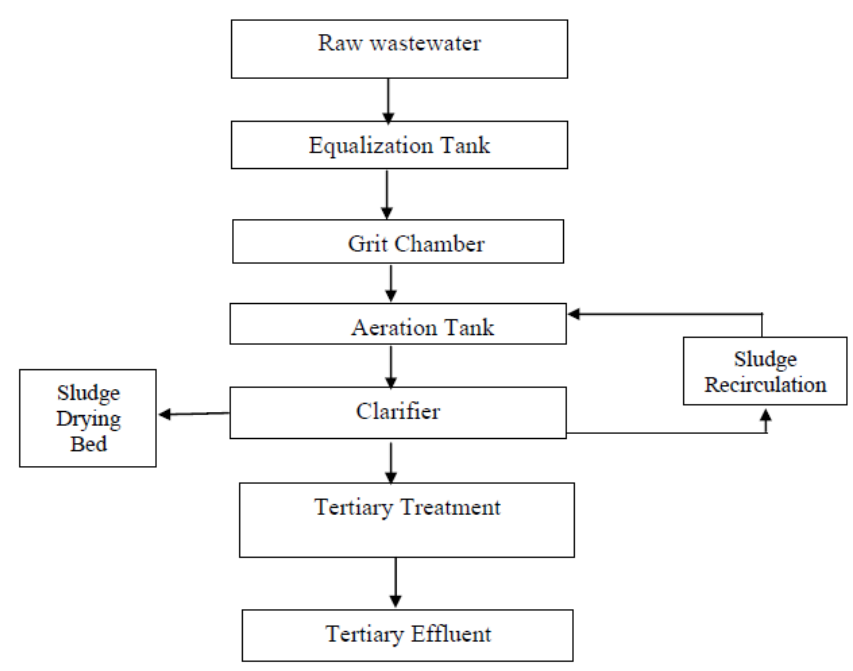

Fig. 1. Process flow diagram of extended aeration sludge process.

\section{B. Jahra Wastewater Treatment Plant}

The Jahra sewage plant is located at the northwest of Kuwait City and adjacent to Jahra satellite town. It started operation in 1983 with an average design capacity of 86,000 $\mathrm{m}^{3} / \mathrm{d}$. Present inflow is $65,000 \mathrm{~m}^{3} / \mathrm{d}$. The plant consists of extended-aeration activated sludge process with clarifier, chlorination, and tertiary filtration. As it has no primary clarifiers, raw wastewater flows directly from the preliminary treatment (coarse screening and grit removal) level to EASP 
units and then to the tertiary treatment (sand filtration and chlorination) units. The Sludge is wasted from the aeration basins and thickened in a sludge thickener before spreading thickened sludge on drying beds. Dried sludge is removed from the plant by truck loads. Design criteria of the EASP unit in the plant appear in Table I.

TABLE I: TECHNICAL DATA ON THE EASP UNIT OF JAHRA WASTEWATER TREATMENT Plant (SOURCE: PERSONAL COMMUNICATION, JAHRA Plant TECHNICAL MANAGEMENT)

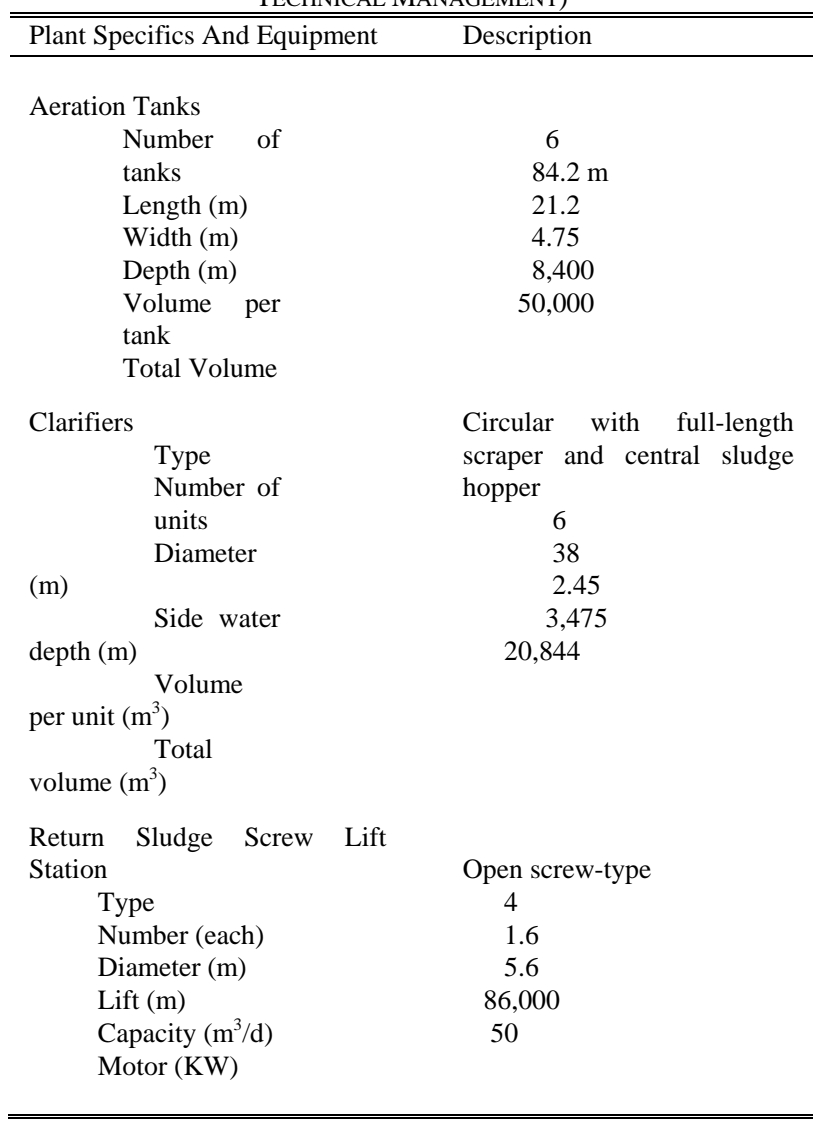

It provides treatment up to tertiary level with sand filtration and disinfection at the final stages. The bulk of the effluent of the plant is sent to central reservoir of irrigation water supply at, Data Monitoring Centre (MPW). Part of the effluent is used by site irrigation and tanker supply to irrigation sites. A small portion of the effluent is occasionally discharged to sea.

\section{MATERIAL AND METHODS}

\section{A. Monitoring Jahra Plant}

The Jahra plant samples were collected in two distinct groups:

- Weekly samples from unit processes.

- Extensive-day monitoring

Samples were collected once in each week from designated locations for 12 months starting from May 2004 and ending in April, 2005. The sampling locations were selected with a purpose of determination of performances of unit processes in the plant. The sample points were:

- Jahra Raw Wastewater line

- Aerator effluent line

- Clarifier Effluent line
All analysis in the laboratory were performed according to the Standard Methods [6]. The purpose of these long-term data collection at regular week interval was to observe average trend and unusual variations in inflow and unit performances through a year-long period.

\section{B. Sample Analysis}

All samples were analyzed at WRP laboratory at Sulaibiya according to standard methods. Jahra plant inflow records were adopted directly from the plant flow records. In addition, several parameters such as $\mathrm{BOD}_{5}, \mathrm{COD}$, oil and grease, and TSS determined at Jahra plant laboratory.

\section{RESULTS AND DiSCUSSION}

\section{A. Quality of Influent Raw Wastewater}

The data collected from influent and effluent lines of the extended aeration unit were statically analyzed to investigate the performance of activated sludge process in Jahra treatment plant. Table II summarize the measurement and results obtained from statistical analysis during this investigation. The tested parameters include TSS, VSS, COD, BOD, oil/grease, TN and TP. The analysis includes maximum, minimum, mean average and standard deviation values. As shown in Table II average TSS in inflow stream is $173 \mathrm{mg} / \mathrm{L}$ while average VSS is $111 \mathrm{mg} / \mathrm{L}$. VSS/TSS ratio is about $65 \%$ whereas the typical wastewater has VSS/TSS ratio of $75 \%$ [7]. $\mathrm{BOD}_{5}$, which indicates the biodegradable organic load, has an average of $173 \mathrm{mg} / \mathrm{L}$ with maximum and minimum values of 240 and $143 \mathrm{mg} / \mathrm{L}$ respectively. Whereas COD which represents the content of organic matter that can be oxidized by strong oxidizing agents has an average of 266 $\mathrm{mg} / \mathrm{L}$ with maximum and minimum values of 330 and 225 $\mathrm{mg} / \mathrm{L}$ respectively. COD may represent toxic compounds those are of industrial origin and toxic to biological life. Average ratio of BOD/COD found in Jahra plant is about $65 \%$ while usual ration in domestic wastewater plants is about $75 \%$. Therefore, COD measurement indicate that there is no industrial waste flux in the sewer system. Average TN content in influent is $38.38 \mathrm{mg} / \mathrm{L}$ while its maximum and minimum values are $58.2 \mathrm{mg} / \mathrm{L}$ and $27.4 \mathrm{mg} / \mathrm{L}$ respectively. These measurements within normal range of domestic wastewater [7]. Average concentration of $\mathrm{NH}_{3}{ }^{-}$is $19.27 \mathrm{mg} / \mathrm{L}$ with maximum and minimum values of $31 \mathrm{mg} / \mathrm{L}$ and $13 \mathrm{mg} / \mathrm{L}$ respectively. The relatively high fraction of $\mathrm{NH}_{3}{ }^{-}$reveals that the sewer system is under anaerobic condition and dissolved oxygen (D.O) in inflow wastewater is very low. Average TP content in influent is $23.57 \mathrm{mg} / \mathrm{L}$ while its maximum and minimum values are $34.3 \mathrm{mg} / \mathrm{L}$ and $15.4 \mathrm{mg} / \mathrm{L}$ respectively. The high phosphorus concentration in the influent might be due to excessive use of detergents for domestic cleaning purposes.

\section{B. Effluent Quality of EASP}

In this study removal of TSS, VSS, BOD, COD. TN and TP was used to investigate the performance of the activated sludge process of Jahra wastewater treatment plant. The results of all analyses are summarized and presented as mentioned earlier in Table 2. The results represent the 
chemical analysis of maximum, minimum and average of activated sludge process influent and effluent streams. Fig. 2, 3,4 and 5 show graphic presentation of the performance for the system in term of the reduction of values of TSS/VSS, $\mathrm{BOD}, \mathrm{COD}, \mathrm{TN}$ and $\mathrm{TP}$, respectively. In addition, average removal efficiency of the tested parameters is presented in Fig. 6.

TABLE II: ANALYSIS OF RAW WASTEWATER AND SECONDARY CLARIFIER EFFLUENT

\begin{tabular}{|c|c|c|c|c|c|c|c|c|}
\hline \multirow{2}{*}{ Parameters } & \multicolumn{3}{|c|}{ Influent Raw Water } & \multicolumn{5}{|c|}{ Clarifier Effluent } \\
\hline & Max & Min & Ave & Std & $\operatorname{Max}$ & Min & Ave & Std \\
\hline TSS (mg/L) & 261 & 132 & 173 & 40.4 & 33.7 & 17.7 & 23 & 5.45 \\
\hline $\begin{array}{l}\text { COD } \\
(\mathrm{mg} / \mathrm{L})\end{array}$ & 330 & 225 & 266 & 33.1 & 72.3 & 38.7 & 50 & 11.26 \\
\hline $\begin{array}{l}\text { BOD } \\
(\mathrm{mg} / \mathrm{L})\end{array}$ & 240 & 143 & 173 & 29 & 33.5 & 19.5 & 25.6 & 5.1 \\
\hline $\begin{array}{l}\text { VSS } \\
(\mathrm{mg} / \mathrm{L})\end{array}$ & 138 & 92 & 111 & 12.75 & 23.3 & 13.6 & 17.95 & 3.24 \\
\hline $\begin{array}{l}\text { Oil/grease } \\
(\mathrm{mg} / \mathrm{L})\end{array}$ & 37 & 18 & 25.73 & 5.6 & 1.6 & 1.2 & 1.32 & 0.11 \\
\hline $\begin{array}{l}\mathrm{N}-\mathrm{NH}_{3} \\
(\mathrm{mg} / \mathrm{L})\end{array}$ & 31 & 13 & 19.27 & 6.15 & 11.3 & 5.10 & 6.89 & 1.76 \\
\hline $\mathrm{TN}(\mathrm{mg} / \mathrm{L})$ & 58.2 & 27.4 & 38.35 & 10.4 & 27 & 10.20 & 16.25 & 4.89 \\
\hline $\begin{array}{l}\text { TP-PO }{ }_{4}{ }^{-} \\
(\mathrm{mg} / \mathrm{L})\end{array}$ & 34.3 & 15.4 & 23.57 & 5.92 & 22.10 & 6.90 & 13.65 & 4.98 \\
\hline
\end{tabular}

As shown in Table II and Fig. 2 the average effluent concentrations of TSS and VSS are $23 \mathrm{mg} / \mathrm{L}$ and $18 \mathrm{mg} / \mathrm{L}$ respectively. Average VSS/TSS ratio of 0.78 reveals that the volatile content is relatively high in the suspended solids of the activated sludge process effluent. As shown in Fig. 7 the average removal efficiencies of the system for TSS and VSS were $86.3 \%$ and $83.5 \%$, respectively. The results clearly show the effectiveness of secondary clarifier in solid separation. The BOD and COD measurements of secondary clarifier effluent are shown in Fig. 3 and 4 respectively. BOD concentration in the effluent is varied from 19.5-33.5 mg/L with an average value of $25 \mathrm{mg} / \mathrm{L}$. Whereas the COD values are ranged between 38.7 to $72.3 \mathrm{mg} / \mathrm{L}$, with an average value of $50 \mathrm{mg} / \mathrm{L}$. The average removal efficiencies of the system for BOD, COD were $85 \%$ and $81 \%$, respectively (Fig.7). This significant reductions in both COD and BOD values revealed that the heterotrophic bacteria which is responsible of degrading the carbonaceous organic were rich in the aeration tanks. In addition, it is possible that long detention time in aeration tank enhances the removal efficiency of BOD.

Average TN in effluent wastewater is $16 \mathrm{mg} / \mathrm{L}$ while its maximum and minimum values are 27 and $10 \mathrm{mg} / \mathrm{L}$, respectively (Fig. 5). As shown in Fig. 7 the average removal efficiency of $\mathrm{TN}$ is $57 \%$. Usually nitrogen removal domestic wastewater treatment is occurred in two-step processes: nitrification followed by denitrification. In this context, low nitrogen reduction obtained in this study indicates that the nitrification/denitrification process was incomplete. This is common in conventional activated sludge system with poor anoxic conditions. In such system bacteria for the purpose of cell production use only small fraction of nitrogen and the rest remains in wastewater. For better nitrogen reduction, a denitrification process must be improved by creating anoxic conditions in the system. Fig. 6 depicts the variation of TP concentration for the influent and effluent The influent TP was fluctuating during the period of operation between 1.4 and $34.3 \mathrm{mg} / \mathrm{L}$ with an average value of $23 \mathrm{mg} / \mathrm{L}$. Whereas, the effluent TP concentration was varied from 6.9-22.1 mg/L with an average value of $13.6 \mathrm{mg} / \mathrm{L}$. As Fig. 7 depicts the average, removal of $\mathrm{TP}$ is $43 \%$. This restively poor elimination of phosphate is expected in this type of conventional processes. The incomplete phosphorus removal may resulted from carbon substrate competition between phosphorus accumulating organisms (PAOs) and the denitrifying bacteria.

Many researchers investigating conventional domestic wastewater treatment plant utilizing EASP reported similar observation of limited nutrients reduction [8]-[12].

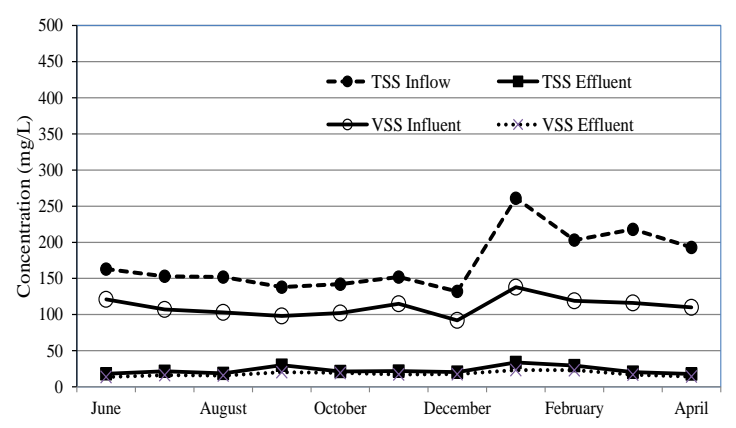

Fig. 2. Monthly variations in TSS and VSS for influent and effluent of EASP.

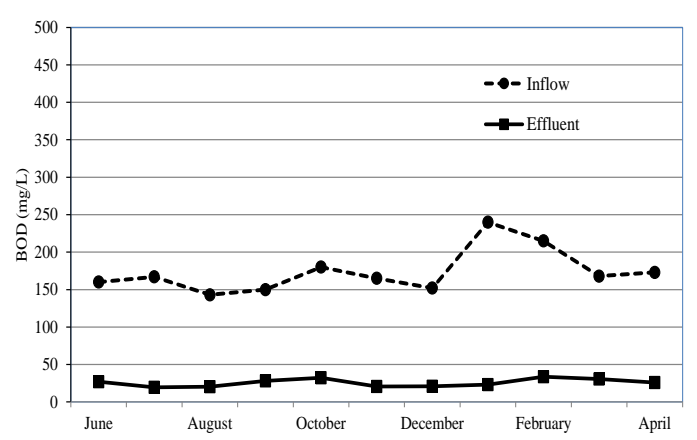

Fig. 3. Monthly variations in BOD for influent and effluent of EASP.

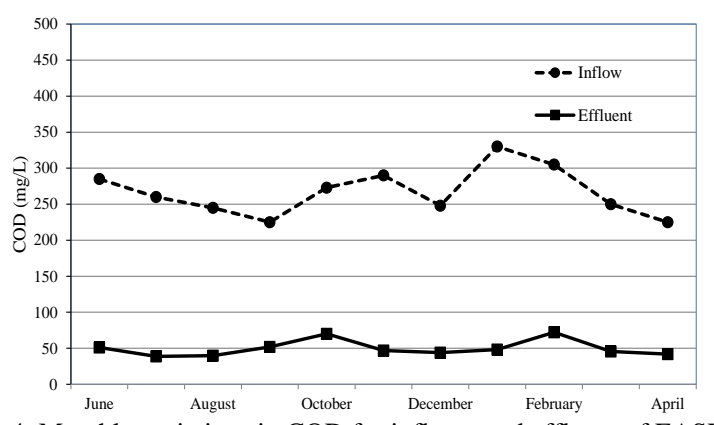

Fig. 4. Monthly variations in COD for influent and effluent of EASP.

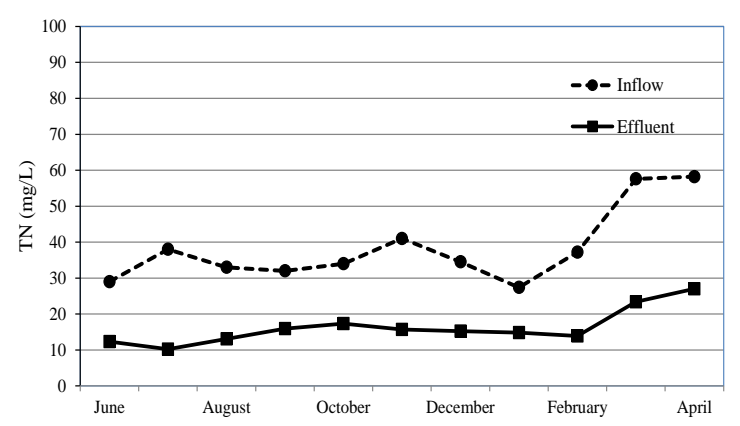

Fig. 5. Monthly variations in TN for influent and effluent of EASP. 


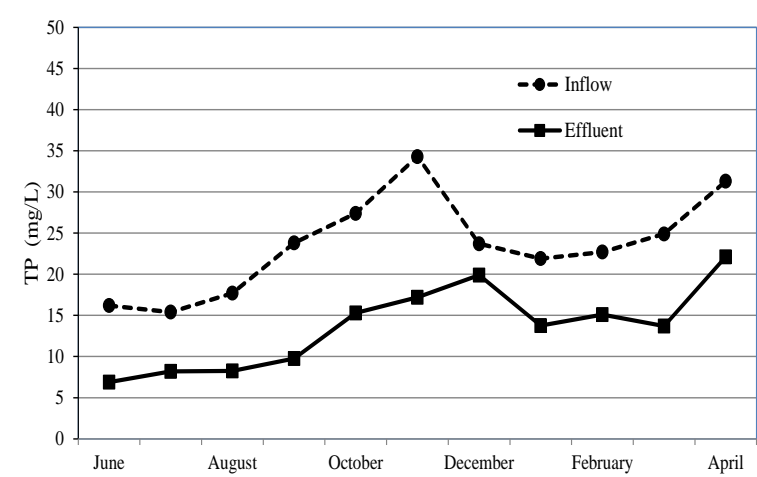

Fig. 6. Monthly variations in TP for influent and effluent of EASP.

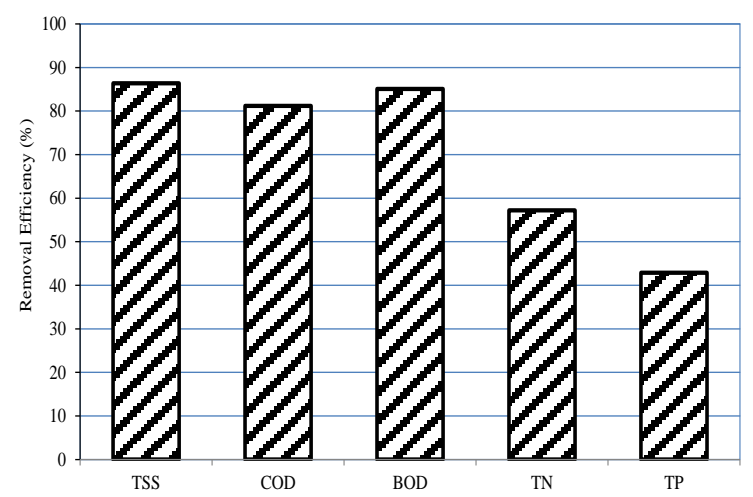

Fig. 7. Removal efficiency of tested parameters of EASP.

\section{CONCLUSIONS}

The objective of this study is to evaluate the performance of extended aeration sludge process in Jahra wastewater treatment plant. Based on the results, the following conclusions are made:

- Raw wastewater of Jahra treatment plant has typical characteristics of weak-to-medium domestic wastewaters.

- High removal efficiency was achieved for TSS, BOD and COD compared to conventional activated sludge process.

- Average ratio of BOD/COD found in Jahra plant is about $65 \%$ while usual ration in domestic wastewater plants is about $75 \%$.

- COD measurement indicate that there is no industrial waste flux in the sewer system.

\section{ACKNOWLEDGMENTS}

The authors would like to thank Kuwait Institute for Scientific Research for funding the study. Data used in this study were collected during the execution of a project entitled "Monitoring and performance evaluation of an activated sludge process treating municipal wastewater in Kuwait - A Case Study".

\section{REFERENCES}

[1] E. Aleisa, K. Al-Shayji, and R. Al-Jarallah, "Residential wastewater treatment system in Kuwait," in Proc. 2nd International Conference on Environmental Science and Technology, vol. 6, no. 7, pp. 285-289, 2011.

[2] B. Al-Anzi, A. Abusam, and A. Shahalam, "Assessment of wastewater reuse in Kuwait and its impact on amount of pollutants discharged into the sea," Journal of Environmental Protection, vol. 3, pp. 935-939, 2012.

[3] A. Bhargava, "Activated sludge treatment process-concept and system design," International Journal of Engineering Development and Research, vol. 4, issue 2, pp. 890-896, 2016.

[4] G. E. MacCulloch, "Evaluation of an extended aeration treatment plant," Master dissertation, Dept. Civil Eng., University of Arizona, 1970.

[5] J. Amarnath, R. Thamilamudhan, and S. Rajan, "Comparative study on wastewater using activated sludge process and extended aeration sludge process," Journal of Chemical and Pharmaceutical Research, vol. 7, no. 1, pp. 798-802, 2015.

[6] APHA, "Standard methods for the examination of water and wastewater," 21st Edn, American Public Health Association, Washington, 2005

[7] Metcalf and Eddy, Inc., Wastewater Engineering: Treatment and Reuse, fourth edition. New York: McGraw-Hill, 2003.

[8] H. P. Fang, C. L. Y. Yeong, K. M. Book, and C. M. Chiu, "Removal of $\mathrm{COD}$ and nitrogen in wastewater using sequencing batch reactor with fibrous packing," Water Science Technology, vol. 28, no. 7, pp. 125-131, 1993.

[9] K. Naddafi, M. S. Hassanvand, E. Dehghanifard, D. F. Razi, D. Mostofi, N. Kasaee, R. Nabizadeh, and M. Heidari, "Performance evaluation of wastewater stabilization ponds in Arak-Iran," Iran. J. Environ. Health. Sci. Eng., vol. 6, no. 1, pp.41-46, 2009.

[10] R. Al-Saed and N. Tomaleh, "Performance evaluation of a full scale extended aeration system in Al-Bireh city, Palestine," Clean-Soil, Air, Water, pp. 1-7, 2012.

[11] D. Sukumaran, R. Saha, and C. Saxena, "Performance evaluation pf prevailing biological wastewater treatment system in west Bengal, India," Applied Ecology and Environmental Sciences. vol. 3, no. 3, pp. $1-4,2015$

[12] M. S. Nikmanesh, H. Eslami et al., "Performance evaluation of the extended aeration activated sludge system in the removal of physicochemical and microbial parameters of municipal wastewater: A case study of Nowshahr wastewater treatment plant," Journal of Environmental Health Sustainable Development, vol. 3, pp. 509-17, 2018.

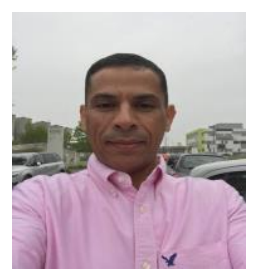

Saud B. Al-Shammari was born in State of Kuwait. In 2002 he received his Ph.D. degree in chemical engineering from Manchester University, UK. After graduation, he was scientific researcher at Water Technologies Department in Kuwait Institute for Scientific Research (KISR). Since 2010 to now, he has been professor associate at Environmental Health Department in Public Authority for Applied Education and Training. His research interests include water and wastewater treatment, environmental engineering and seawater desalination. He has published more than 28 scientific articles, which were published in international journals.

Abulbasher Shahalam was born on Bangladesh in 1942. In 1975 has received his $\mathrm{PhD}$ degree in civil engineering from University of Toledo, USA. His major fields of interest span environmental engineering with specific research work undertaken in biological treatment of wastewater and pollutant migration through soil and ground water. He has published more than 80 journal publications. 